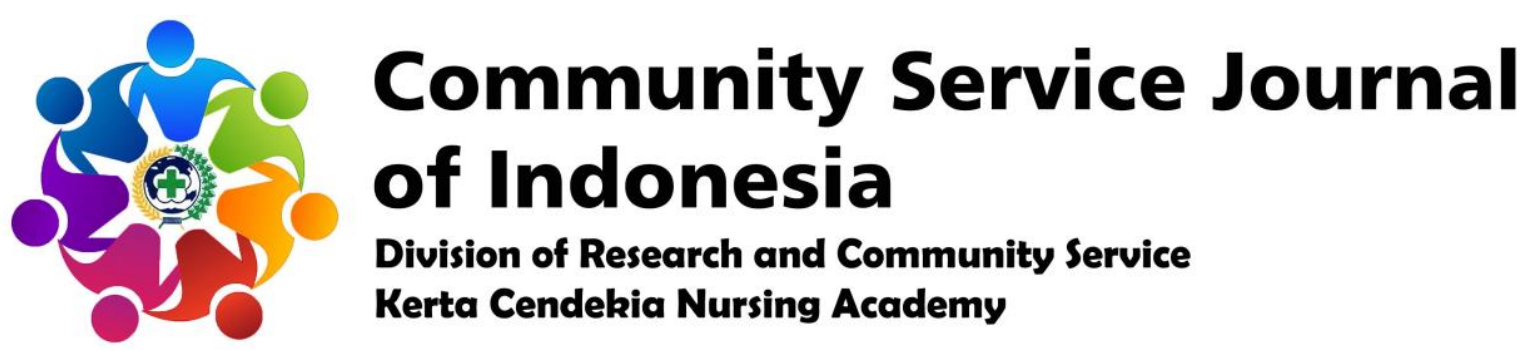

https://ejournal-kertacendekia.id/index.php/csji/index

\author{
Community Service Journal of Indonesia 2 (2) (2020): 18-20 \\ Doi: https://doi.org/10.36720/csji.v2i2.250
}

\title{
KNOWLEDGE IMPROVEMENT OF YOUTH ABOUT THE IMPACT OF PROMISCUITY
}

\section{Meli Diana ${ }^{1 *}$, Elvira Bella Chinthia ${ }^{2}$, Riscahyani Sartika Ningrum ${ }^{2}$, Nurul Jannah ${ }^{2}$, Fifiyanti Yosefina $^{2}$}

${ }^{1}$ Lecturer of Kerta Cendekia Nursing Academy, Sidoarjo

${ }^{2}$ Students of Kerta Cendekia Nursing Academy, Sidoarjo

\author{
* Correspondence \\ Meli Diana \\ Kerta Cendekia Nursing Academy, Sidoarjo \\ Lingkar Timur Road, Rangkah Kidul Village, Sidoarjo Sub-District, \\ Sidoarjo Regency, East Java Province, Indonesia - 61234 \\ Email: melidiana159357@gmail.com
}

\begin{abstract}
Health promotion activities regarding the impact of promiscuity in MTs. Islamiyah Tanggulangin Sidoarjo is a form of community service in the form of counseling aimed at increasing children's knowledge about the impacts and dangers of promiscuity which are increasingly prevalent among teenagers today. The implementation of these activities on December 14, 2019 took place at MTs. Islamiyah Tanggulangin Sidoarjo. With the target is MTs students. Islamiyah Tanggulangin Sidoarjo. Prior to the implementation of these activities, there was a process of preparing activities for approximately 2 weeks before the activities were carried out, starting from determining the theme of the extension to applying for permits to the parties concerned. As a form of evaluation, this activity was attended by 76 students from grade VII to grade IX, participants joined the activity happily and looked very enthusiastic, health promotion activities could run on time and smoothly.
\end{abstract}

Keywords: Promiscuity, teenagers, counseling, adolescent reproductive health.

(c) 2020 The Authors. Community Service Journal of Indonesia Published by Community Service and Research of Kerta Cendekia Nursing Academy - Kerta Cendekia Nursing Academy

This is an Open Access Article distributed under the terms of the Creative Commons Attribution 4.0 International License which permits unrestricted non-commercial use, distribution, and reproduction in any medium, provided the original work is properly cited.

E-ISSN

2684-7884

\section{INTRODUCTION}

Promiscuity is a form of deviant behavior that crosses the boundaries of obligations, rules, demands, conditions, and feelings of shame. Free association can also be interpreted as deviant behavior that 
violates religious and moral norms. Promiscuity is a negative behavior as an expression of rejection by adolescents. Some of the causes of adolescents engaging in promiscuity, namely the failure of adolescents to absorb religious norms and norms of Pancasila, unhealthy mental attitudes, disillusionment with unharmonious families, and so on. Association has a great influence on the personality formation process. Teenagers are very vulnerable to being influenced by the interactions that exist in their environment. Teenagers must be smart to avoid promiscuity, because teenagers at the same age are still easily swayed and are looking for identity.

\section{OBJECTIVES}

General Purpose

After 45 minutes of health education, it is hoped that the students in grades VII - IX at MTs. Islamiyah Tanggulangin Sidoarjo can understand about the impact of promiscuity for adolescents.

\section{Special Purpose}

After 45 minutes of health education, it is hoped that the students of class VII - IX MTs. Islamiyah Tanggulangin Sidoarjo can:

1. Understand about adolescent reproductive health.

2. Know the phenomenon of adolescent reproductive health.

3. Know the impact of promiscuity.

4. Know the myths about promiscuity.

\section{PLAN OF ACTION}

Strategy Plan

The strategy plan implemented, including:

1. Coordinate with the head of MTs. Islamiyah Tanggulangin Sidoarjo to apply for permission to implement health education as a nursing program and to help provide useful knowledge for MTs students. Islamiyah Tanggulangin Sidoarjo.

2. Establish time contracts with students of MTs. Islamiyah Tanggulangin Sidoarjo.

3. Providing health education about the impact and dangers of promiscuity.

\section{Implementation}

Actions taken in the implementation of these activities, including:

1. Contacted the head of MTs. Islamiyah Tanggulangin Sidoarjo to request permission to carry out the activity and gather the students of MTs. Islamiyah Tanggulangin Sidoarjo.

2. Prepared a place and media for health education about the impact of promiscuity.

3. Delivery of health education materials about the impact of promiscuity to the students of MTs. Islamiyah Tanggulangin Sidoarjo.

\section{Setting}

This activity was carried out at the MTs. Islamiyah Tanggulangin Sidoarjo on December 14, 2019.

Target

Target in this activity is all of the students of class VII - IX of MTs. Islamiyah Tanggulangin Sidoarjo.

\section{RESULTS AND DISCUSSION}

This activity took place on December 14, 2019 which lasted for one hour starting at $08.00 \mathrm{WIB}$ to $09.00 \mathrm{WIB}$. Activities carried out according to plan. This activity was attended by 76 students who overall seemed enthusiastic in the process of 
delivering health education materials about the impact of promiscuity. This was indicated by the presence of several questions asked by the health education participants. The delivery of material on health education uses language that is easy for the health education participants to understand. The media used in this health education include laptops, powerpoints, videos, leaflets, and posters. Based on the results of the final evaluation carried out, it was found that $90 \%$ of participants were able to explain the notion of adolescent reproductive health, $90 \%$ of participants were able to explain the impact of promiscuity, and $90 \%$ of participants were able to understand the myths that occurred about promiscuity.

\section{CONCLUSION}

Knowledge improvement of youth about the impact of promiscuity can prevent an increase in the incidence of promiscuity among adolescents.

\section{REFERENCES}

-------. (2007). Seks Bebas Remaja Indonesia Merajalela. Retrieved from

https://workshopsalamaa.wordpress .com/2007/04/11/seks-bebasremaja-indonesia-merajalela/.

-------. (2006). Mengatasi Perilaku Seks Bebas. Retrieved from http://ruuappri.blogsome.com/2006 /05/23/mengatasi-perilaku-seksbebas-2/.

Kementerian Kesehatan Republik Indonesia. (2015). Infodatin: Situasi

Kesehatan Reproduksi Remaja.
Jakarta: Kementerian Kesehatan Republik Indonesia.

Nugraha, B. D. (2000). Gynecology and Consultant. Jakarta.

Wijayanto, I. (2008). Cinta antara Realita Seks Pra-Nikah. Jogjakarta. 